\title{
EXPLORING THE SIGNIRCANCE OF MECCA SACRED MOSQUE GLOBAL LOCATION
}

Received January 4th 2017 | Accepted March 6th 2017 | Available online June 15th 2017 | DOI http://dx. doi. org/10.18860/jia.v4i3.3920 |

\section{Yehia Hassan Wazeri}

Dept. of Architecture

High Institute of Engineering and Technology, Al Arish, Egypt.

drwazeri@yahoo.com

\begin{abstract}
In traditional Islamic cities, the great mosque lies in the middle as the main landmark of the city. It is stated in the Qur'an that the Ka'ba (Mecca sacred mosque) was the first house that was built in Mecca city for humanity to worship Allah. Therefore, Mecca is the holiest city of Islam, and the goal of the annual Muslim hajj (pilgrimage). The objective of the present study is to explore the significance of sacred mosque of Mecca global location on dry land by using accurate measurements and Satellite programs. The results of the study illustrate that the sacred mosque of Mecca equally distances away from the following locations:1] The farthest borders edges of Africa and Europe as well, 2) The nearest borders of the new world continents along with a part of Asia which meeting the Northern borders of North America at the Bering Sea, 3) The farthest borders of the new world continents that represent the outer edges of the dry land, 4) Finally, the Ka'ba is equally distant from the geographical centers of the new world continents.
\end{abstract}

\section{KEYWORDS:}

Ka'ba location; Mecca city; Satellite images; Dry land

\section{INTRODUCTION}

The concept of the old Islamic cities is based on having the great mosque in the middle as the main landmark of the city. In traditional Islamic cities, mosques have function and hierarchy, and they are placed in a constant and standard distance from each other. A city's main mosque was the first building that was designed. Then, the urban neighborhood and then the streets and alleys were designed [1].

The city of Baghdad was a direct model on having the great mosque in the middle of the Islamic city. It was designed as a circle about $1 \mathrm{~km}$ in diameter, leading it to be known as the "Round City". The original design shows a ring of residential and commercial structures along the inside of the city walls, but the final construction added another ring, inside the first. In the center of the city lay the mosque and the Caliph palace[2], figure 1.

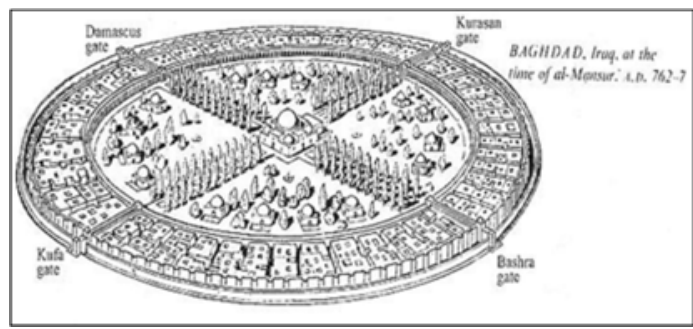

Figure 1. The great mosque lies in the center of Baghdad city
The sacred city of Islam has been mentioned in the Qur'ān by the two names Makkah and Bakkah. Historian Mahmūd Shukrī al-Alūsī (1856-1924) wrote that Makkah refers to the whole city and Bakkah refers to the 'house', specifically the cubic shrine at the centre of the Mosque [3]. This house is also known as the Ka'ba.

It is stated in the Qur'an that the Ka'ba was the first house that was built for humanity to worship Allah. Therefore, Mecca is the holiest city of Islam, and the goal of the annual Muslim hajj (pilgrimage). The important question is: "Does The sacred mosque of Mecca (the Ka'ba) lay in a unique location on the dry land on earth?".

This research aims to explore the significance of Mecca sacred mosque global location on dry land by using accurate measurements to calculate real distances between Ka'ba and selected points at the borders of the old world (i.e. Asia, Africa, and Europe) and the modern (i.e. North America, South America, Australia, and Antarctica) as well.

\section{MECCA AS THE CENTER OF THE DRY LAND}

The Muslim is expected to prostrate towards the Ka'ba when praying, five times a day. Mosques are also expected to face Mecca. There are other rules, like being buried with one's head in the direction of Mecca. All of these activities require knowledge of the Qibla

86 | Journal of Islamic Architecture, 4(3) June 2017 
(direction to Mecca).

The scholars of the Muslim world recognized the qibla problem much, much earlier, possibly as early as the ninth century [4] [5] [6].

Sophisticated mathematical solutions were developed that were based on spherical trigonometry and the geographical knowledge of that period. The most commonly adopted algorithm was based on the great-circle path (or shortest-distance path) connecting the observer with the Ka'ba in Mecca and determining its angle with the direction to North.

From the ninth century onward, various sections of the perimeter of the Ka'ba came to be associated with areas of the Muslim world. The earliest known Ka'ba-centered geographical scheme is recorded in a manuscript of the "Kitab al-masalk wa-almamalik" (Book of routes and provinces) by the ninthcentury scholar Ibn Khurradadhbih. The twelfthcentury Egyptian legal scholar Zayn al-DIn alDimyati, summed it up thus[7]: "The Ka'ba with respect to the inhabited parts of the world is like the center of a circle with respect to the circle. All regions face the Ka'ba, surrounding it as a circle surrounds its center, and each region faces a particular part of the Ka'ba, figure 2.

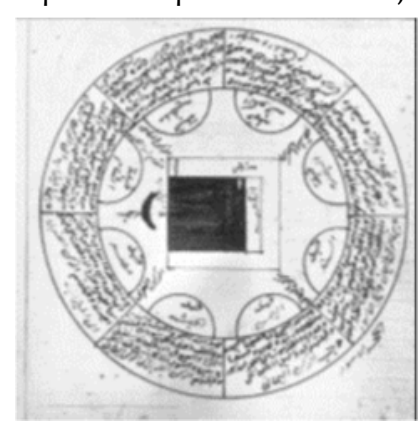

Figure 2. EIGHT DIVISIONS OF THE WORLD ABOUT THE KA'BA. According to an anonymous Ottoman treatise dating from the eighteenth century. The loops pointing toward the Ka'ba in the center contain the names of the regions or cities for which the qibla is defined.

Two Iranian fascinating metal instruments discovered in 1989 and 1995. Both consist of a worldmap centered around Mecca with a rule that enables one to read off the qibla of more than one hundred localities engraved on the map as well as their distance from Mecca. The metalwork is clearly Safavid and can be dated to approximately the year 1700 . Only on one of the two instruments, the European types of compass and sundial that were originally attached to both are still extant [8], figure 3 .

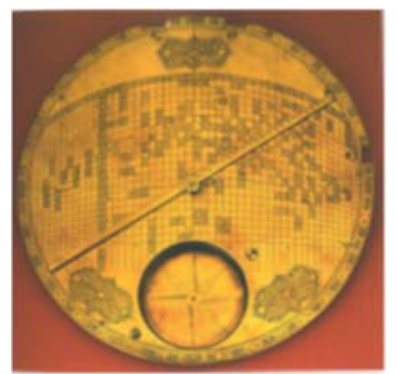

Figure 3. The Iranian Qibla Instrument Found in 1989.
James Ireland Craig created the Craig retroazimuthal map projection in 1909. As Snyder st.ated Azimuthal projections provide accurate directions from the center point of the projection [9]. The Craig retroazimuthal is sometimes known as the Mecca projection because Craig, who had worked in Egypt as a cartographer, created it to help Muslims find their qibla [10].

There are two important studies in the 20th Century on Mecca as the center of the dry land:

The first Study: in the seventies of the 2oth Century, the late Egyptian Dr. Hussein Kamal Ad-Deen observed that Mecca is located in the center of a circle whose circumference passes by the outer borders of new world Continents[11].

Despite this important scientific observation, Prof. Kamal Ad-Deen did not offer scientific proof through accurate scientific measurements at that time. However, the merit of declaring this wonderful discovery in the modern age goes to him.

The second Study: Prof. Dr. Muslim Shaltout, an Egyptian Professor of Sun and Space Research in Astronomy and Geophysics Research Institute in Egypt carried out this study in the nineties of the 2oth Century. He used a computer program that was specially developed to calculate the distance between Mecca and selected points at the edges of the dry land in relation to the old and the new worlds [12].

Despite the importance of this study for adopting a clear scientific methodology, it was limited to a computer-based study, and did not rely on real measurements, on other hand, it was confined to only a few points of measurements, especially in relation to the new world edges. Moreover, some of the measurements were inaccurate. However, this study remains a landmark on the road to prove that Mecca is the center of the dry land. This study also use it while conducting in this field.

\section{USING SATEUTIE PROGRAMS TO DEIERMINE THE KA'BA GLOBALLOCATION}

It is known to all experts and specialists that one cannot depend on normal geographical maps to determine scientific and accurate measurements between two locations or two cities, because they are only drawings represent the projection of the continents of the world. It cannot reflect the real distances and directions at the same time.

\section{COMPUIER PROGRAMS (METHOD OF MEASUREMENTS)}

There are several satellite programs devoted to finding qibla from any place on earth; for example, web sites called "Qibla Direction", "Qibla locator" and "qibla-pointer". These web sites contain a satellitemap based Qibla locator service and allow muslim people to find Qibla direction and calculate the distance between a pair of points specified as latitude and longitude.

This present research utilized two programs that depend on real satellite images of the earth, give 
accurate measurements of the arcing distances and directions between any two points on the surface of the earth. These programs are: (a) Google Earth Pro: A highly efficient program that accurately measures distances between any two points on the earth by capturing real images of the selected part of the earth via satellites. "Google Earth Pro" offers a number of tools that you can use to measure distances, draw circles and make videos[13]. (b) Qibla-pointer: A highly efficient program locates the Qibla at any point on the earth and measure the distance between any point on the earth and Mecca with ultimate accuracy, using satellite images[14]. By using the above mentioned programs, arcing distances between the Ka'ba and four groups of points were accurately measured. The results reached by "Google Earth Pro." and "Qiblapointer" Program were consistent with "Distance Calculator program" which uses calculations for latitude/longitude points with the formula and code fragments for implementing them. All these formulas are for calculations based on a spherical earth (ignoring ellipsoidal effects) - which is accurate enough for most purposes [In fact, the earth is very slightly ellipsoidal; using a spherical model gives errors typically up to $0.3 \%][15]$.

This uses the 'haversine' formula to calculate great-circle distances between the two points - that is, the shortest distance over the earth's surface - giving an 'as-the-crow-flies' distance between the points (ignoring any hills).

\section{POINTS OF MEASUREMENTS}

Based on studies on the shape of the outer borders of the seven known Continents, four groups of points were selected for measuring their distances from the Ka'ba (21.25N Lat. and 39.49E Long.)[16], figure 4 .

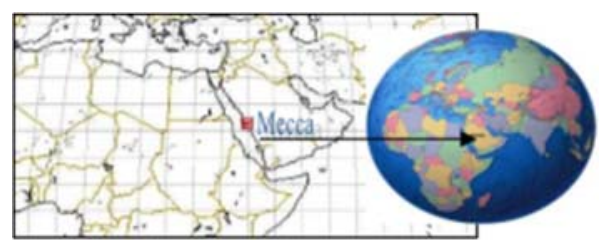

Figure 4: Global location of Mecca sacred mosque (the Ka'ba)

The first third groups were determined by drawing circles (using "Google Earth Pro" Program) from the Ka'ba touched the farthest points at the edges of the seven Continents, figure 5 .

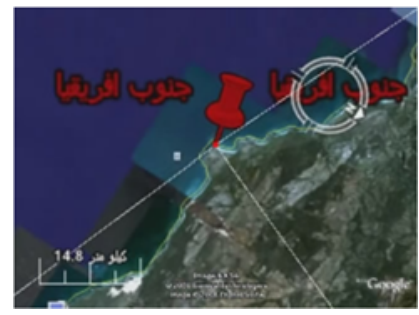

Figure 5: Three groups of points were determined by drawing circles from the Ka'ba touched the farthest borders of the Seven Continents' (Example: The farthest point in the Southern coast of Africa) (The researcher)
The fourth group of points represent the geographical centers of the new world continents. In geography, the centroid of a region of the Earth's surface, projected radially onto said surface, is known as its geographical center[17]. That is mean the geographical center of any continent is the point that represents the center of this continent's area.

The four groups of points are as follows:

a) The farthest points from the Ka'ba at the edges of the old world continents. These points are as follows: *The farthest point in the Southern coast of Africa (18.32 Long., -34.14 Lat.). *The farthest point in the western coast of Africa (-17.52 Long., 14.74 Lat.). *The farthest point in Europe (western coast of Iceland) (-23.56 Long., 65.40 Lat.);

b) The nearest points to the Ka'ba at the edges of the new world continents. These points are as follows: *The nearest point in the Western coast of Australia (113.55 Long., -21.58 Lat.). *The nearest point in the Northern coast of Antarctica (53.78 Long., -65.51 Lat.). *The nearest point in the Eastern coast of South America (-35.15 Long., -5.29 Lat.). *The nearest point in the Eastern coast of North America (-52.73 Long., 47.87 Lat.). * Meeting Point of Asia and North America (at Bering Sea) (-168.46 Long., 66.00 Lat.). *The Farthest point of Asia ( The Eastern coast of Japan) (140.52 Long., 35.42 Lat.);

c) The farthest points from the Ka'ba at the edges of the new world continents. These points are as follows: *The farthest point in the Eastern coast of Australia (153.55 Long., -28.50 Lat.). *The farthest point in the Southern coast of Antarctica ( -126.73 Long., 73.15Lat.). *The farthest point in the Southern coast of South America (-67.93 Long., -55.72 Lat.). *The farthest point in the Western coast of South America ( -81.47 Long., -6.00 Lat.). *The farthest point in the Western coast of Central America (-91.23 Long., 14.22 Lat.). *The farthest point in the Western coast of North America (109.59 Long., 22.52 Lat.);

d) The geographical centers of the new world continents are determined as follows: *In 1988, The Royal Geographical Society of Australia located the geographical center of Australia (134.21 Long., -25.36 Lat.) [18], [19]. *The U.S Geological Survey determined the geographic center of North America in the city of Rugby, North Dakota (-99.35 Long., 48.12 Lat.) [20], [21]. *The geographical center of South America is Cuiabá the capital city of the Brazilian state of Mato Grosso (-56.05 Long., -15.35 Lat.) [22]. *Joe McCollum located the geographical center of Antarctica using mathematical models (79.81 Long., -85.90 Lat.) [19].

\section{RESULTS AND DISCUSSION}

\section{DISTANCES BETWEEN THE KA'BA AND THE FARTHEST POINTS IN THE OLD WORID CONTINENIS (ARICA AND EUROPE)}

The measurements showed that the average distance between the farthest borders in continents Africa and Europe (Iceland) is $6449 \mathrm{~km}$, figure 6. See also results of the measurements in table 1 . The Deviation degree of measurements ranging from $2.17 \%$

88 | Journal of Islamic Architecture, 4(3) June 2017 
(143 Km.) to $5.70 \%$ (366 Km.).

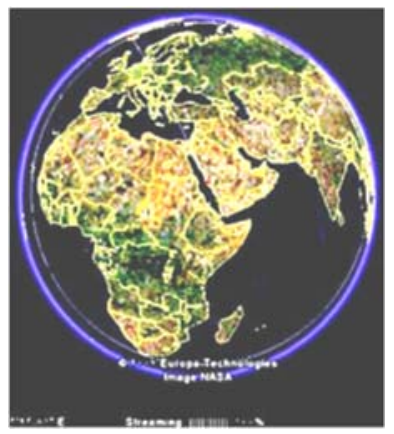

Figure 6: A real satellite image shows that Ka'ba is located in the center of a circle that passes through the farthest points at the edges of the Old world Continents (Africa and Europe). (The researcher).

A part of Asia was not included in the previous distance due to the vast area of this continent. The remaining part of Asia will be included in the measurements of the new world borders. That is because the farthest point in Asia meets the farthest one in the northern borders of North America at Bering Sea. This fact was unknown until the North and South Americas were discovered.

Table 1: The distance between the Ka'ba and the farthest points at the edges of the old world Continents (the Researcher).

\begin{tabular}{cccccc}
\hline Continent & $\begin{array}{c}\text { Location } \\
\text { (Qibla } \\
\text { direction) }\end{array}$ & Longitude & Latitude & $\begin{array}{c}\text { Arc } \\
\text { distance } \\
(\mathbf{k m})\end{array}$ & $\begin{array}{c}\text { Deviation } \\
\text { degree }\end{array}$ \\
\hline 1-Africa. & $\begin{array}{c}\text { South Africa } \\
\left(23.41^{\mathrm{N}}\right)\end{array}$ & 18.32 & -34.14 & 6592 & $2.17 \%$ \\
\hline 2-Africa. & $\begin{array}{c}\text { Western } \\
\text { Coast } \\
\left(73.95^{\circ} \mathrm{N}\right)\end{array}$ & -17.52 & 14.74 & 6083 & $5.70 \%$ \\
\hline 3- Europe. & $\begin{array}{c}\text { Iceland } \\
\left(105.37^{\circ} \mathrm{N}\right)\end{array}$ & -23.56 & 65.40 & 6672 & $3.35 \%$ \\
\hline Average & & & & 6449 & $\mathbf{0} \%$ \\
distance. & & & & & \\
\hline
\end{tabular}

\section{DISTANCES BETWEEN THE KA'BA AND THE NEAREST POINTS}

\section{ATTHE EDGES OF THE NEW WORID CONTINENTS}

It was found that the average distance between the Ka'ba and the nearest borders in the new world continents, in addition to the meeting point of Asia and North America at Bering Sea are $9306 \mathrm{~km}$. figure 7 .
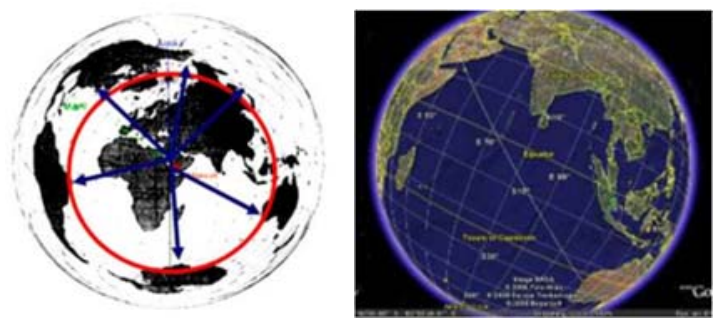

Figure 7: Tow real satellite photos show the measurement lines between the Ka'ba, the western coast of Australia and the eastern coast of South America.) (The researcher).

The result of the measurements is shown in table 2. The Deviation degree of measurements ranging from $0.60 \%(54 \mathrm{Km}$.) to $9.10 \%(853 \mathrm{Km}$.).
Table 2: Distances between the Ka'ba, and the nearest borders at the new world Continents and the farthest location in Asia and North America (the Researcher).

\begin{tabular}{|c|c|c|c|c|c|}
\hline Continent & $\begin{array}{l}\text { Location } \\
\text { (Qibla } \\
\text { direction) }\end{array}$ & $\begin{array}{l}\text { Longi- } \\
\text { tude }\end{array}$ & Latitude & $\begin{array}{c}\text { Arc } \\
\text { dis- } \\
\text { tance } \\
(\mathrm{km})\end{array}$ & $\begin{array}{l}\text { Devia- } \\
\text { tion } \\
\text { degree }\end{array}$ \\
\hline 1-Australia. & $\begin{array}{c}\text { Western } \\
\text { Coast. } \\
(295.81 \mathrm{~N})\end{array}$ & 113.55 & -21.58 & 9360 & $0.60 \%$ \\
\hline 2-Antarctica. & $\begin{array}{l}\text { Northern } \\
\text { Coast. }\end{array}$ & 53.78 & -65.51 & 9750 & $5.5 \%$ \\
\hline $\begin{array}{l}\text { 3-South } \\
\text { America. }\end{array}$ & $\begin{array}{c}\text { Eastern Coast. } \\
\left(66.81^{\circ} \mathrm{N}\right)\end{array}$ & -35.15 & -5.29 & 8693 & $6.6 \%$ \\
\hline $\begin{array}{l}\text { 4- North } \\
\text { America. }\end{array}$ & $\begin{array}{c}\text { Eastern Coast } \\
\left(73.45^{\circ} \mathrm{N}\right)\end{array}$ & -52.73 & 47.87 & 8453 & $9.1 \%$ \\
\hline 5- Bering Sea. & $\begin{array}{l}\text { Meeting Point } \\
\text { of Asia and } \\
\text { North } \\
\text { America. } \\
\left(333.22^{\circ} \mathrm{N}\right)\end{array}$ & $\begin{array}{l}-168.46 \\
\end{array}$ & 66.00 & 10000 & $7 \%$ \\
\hline 6-Asia. & $\begin{array}{l}\text { Eastern Coast } \\
\text { of Japan. } \\
\left(293.67^{\circ} \mathrm{N}\right)\end{array}$ & 140.52 & 35.42 & 9578 & $3 \%$ \\
\hline $\begin{array}{l}\text { Average } \\
\text { Distance. }\end{array}$ & & & & 9306 & $0 \%$ \\
\hline
\end{tabular}

DISTANCES BETWEEN THE KA'BA AND THE FARTHEST POINIS ATTHE EDGES OF THE NEW WORID CONTINENTS

It was found that the average distance between the Ka'ba and the farthest borders of the new world continents are $13611 \mathrm{~km}$, figure. 8 .

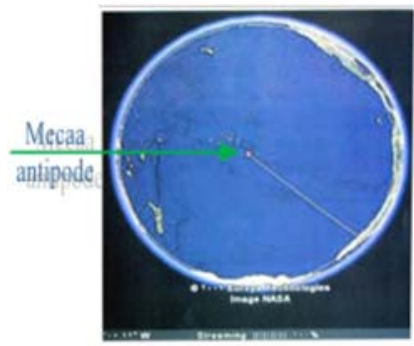

Figure 8: A real satellite image illustrating the circle whose center is the Ka'ba. This image is taken from the Pacific Ocean direction that is exactly opposite to Mecca on the other side of the earth (The researcher).

The results of the measurements in table 3. The Deviation degree of measurements ranging from $1.20 \%$ (161 Km.) to $4.30 \%(608 \mathrm{Km}$.).

Table 3: Distances between the Ka'ba and the farthest borders at the new world Continents (The Researcher).

\begin{tabular}{cccccc}
\hline Continent & $\begin{array}{c}\text { Location } \\
\text { (Qibla } \\
\text { direction) }\end{array}$ & Longitude & Latitude & $\begin{array}{c}\text { Arc } \\
\text { distance } \\
(\mathbf{k m})\end{array}$ & $\begin{array}{c}\text { Deviation } \\
\text { degree }\end{array}$ \\
\hline 1- Australia. & $\begin{array}{c}\text { Eastern } \\
\text { Coast. } \\
\left(279.47^{\circ} \mathrm{N}\right)\end{array}$ & 153.55 & -28.50 & 13384 & $1.67 \%$ \\
\hline 2-Antarctica. & $\begin{array}{c}\text { Southern } \\
\text { Coast. } \\
\left(164.13^{\circ} \mathrm{N}\right)\end{array}$ & -126.73 & -73.15 & 14219 & $4.30 \%$ \\
\hline $\begin{array}{c}\text { 3- South } \\
\text { America. }\end{array}$ & $\begin{array}{c}\text { Southern } \\
\text { Coast. } \\
\left(91.47^{\circ} \mathrm{N}\right)\end{array}$ & -67.93 & -55.72 & 13080 & $4 \%$ \\
\hline $\begin{array}{c}\text { 4- South } \\
\text { America. }\end{array}$ & $\begin{array}{c}\text { Western } \\
\text { Coast. } \\
\left(68.58^{\circ} \mathrm{N}\right)\end{array}$ & -81.47 & -6.00 & 13450 & $1.20 \%$ \\
\hline $\begin{array}{c}5 \text { - Central } \\
\text { America. }\end{array}$ & $\begin{array}{c}\text { Western } \\
\text { Coast. } \\
\left(54.39^{\circ} \mathrm{N}\right)\end{array}$ & -91.23 & 14.22 & 13433 & $1.30 \%$ \\
\hline $\begin{array}{l}\text { 6- North } \\
\text { America. }\end{array}$ & $\begin{array}{c}\text { Western } \\
\text { Coast. } \\
\left(35.80^{\circ} \mathrm{N}\right)\end{array}$ & -109.59 & 22.52 & 14102 & $3.50 \%$ \\
\hline $\begin{array}{l}\text { Average } \\
\text { distance. }\end{array}$ & & & 13611 & $\mathbf{0} \%$ \\
\hline
\end{tabular}




\section{DISTANCES BETWEEN THE KA'BA AND THE GEOGRAPHICAL CENIERS OF THE NEW WORID CONTINENTS}

It was found that the average distance between the Ka'ba and the geographical centers of the new world continents (i.e. Australia, the two Americas, and Antarctica) are $11482 \mathrm{~km}$., figure 9.
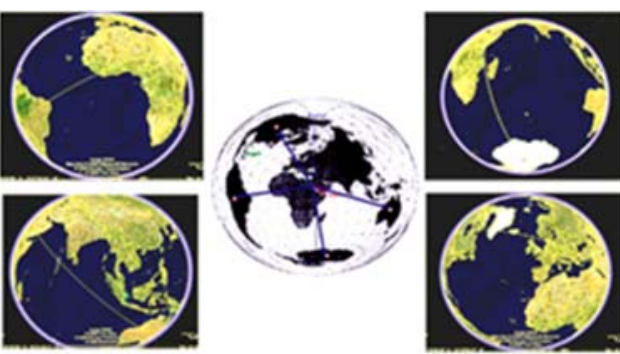

Figure 9: Real satellite images showing the measurement lines between the Ka'ba and the geographical centers of the new world Continents (The researcher).

Results of the measures between the Ka'ba and the geographical centers of the new world continents are illustrated in table 4. The Deviation degree of measurements ranging from $1 \%(58 \mathrm{Km}$.) to $4.70 \%$ (518 Km.).

Table 4: The distance between the Ka'ba and the geographica centers of the new world Continents (the Researcher).

\begin{tabular}{cccccc}
\hline $\begin{array}{c}\text { Continent } \\
\text { Geograph- } \\
\text { ical } \\
\text { center. }\end{array}$ & $\begin{array}{c}\text { (Qibla } \\
\text { direction) }\end{array}$ & Longitude & Latitude & $\begin{array}{c}\text { Arc } \\
\text { distance } \\
(\mathbf{k m})\end{array}$ & $\begin{array}{c}\text { Deviation } \\
\text { degree }\end{array}$ \\
\hline Australia & $\left(287.90^{\circ} \mathrm{N}\right)$ & 134.21 & -25.36 & 11424 & $0.50 \%$ \\
\hline Antarctica. & $\left(320.96^{\circ} \mathrm{N}\right)$ & $79.81-$ & 85.90 & 12000 & $4.50 \%$ \\
\hline $\begin{array}{c}\text { South } \\
\text { America. }\end{array}$ & $\left(70.51^{\circ} \mathrm{N}\right)$ & -56.05 & -15.35 & 11203 & $2.40 \%$ \\
\hline $\begin{array}{c}\text { North } \\
\text { America. }\end{array}$ & $\left(38.38^{\circ} \mathrm{N}\right)$ & -99.35 & 48.12 & 11302 & $1.50 \%$ \\
\hline $\begin{array}{c}\text { Average } \\
\text { distance. }\end{array}$ & & & & $\mathbf{1 1 4 8 2}$ & $\mathbf{0} \%$ \\
\hline
\end{tabular}

The previous results illustrate that the Ka'ba (the sacred mosque of Mecca) equally distances away with a slight deviation from the following borders, figure 10: The farthest points at the edges of Africa and Europe as well; The nearest points at the edges of the new world continents along with the remaining part of Asia which meeting the northern borders of North America at the Bering Sea; The farthest points at the edges of the new world continents that represent the outer edges of the dry land; Finally the Ka'ba is equally distant from the geographical centers of the new world continents.

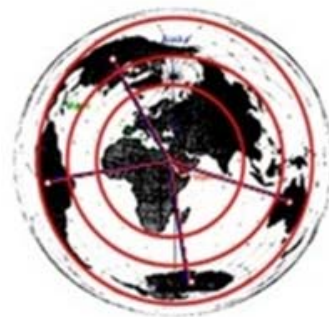

Figure 10: The Ka'ba is the Center of three circles that nearly pass through the edges of the dry land of the old and new world. The fourth one passes through the geographical centers of the new world continents (The researcher).
Upon conducting all the previous measurements with some other mosques and locations (Jerusalem mosque [23], Medina mosque [24], Greenwich city [25] and the geographical center of the seven continents [26]), It was not find that any of them achieves what is achieved by the distinguished global location of Mecca's (the Ka'ba).

The equidistant azimuthal projection, centered on Mecca taken from Waldo Tobler's PowerPoint presentation [27], [28], figure 12, also showed that Mecca is the only location on the earth that can be located in a unique location on the dry land, represented by the seven known continents .

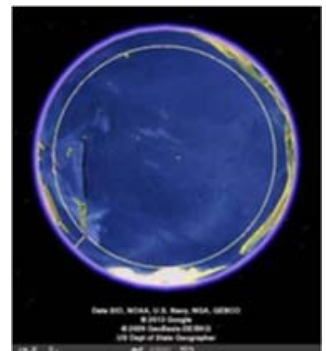

a Circle of Jerusalem mosque.

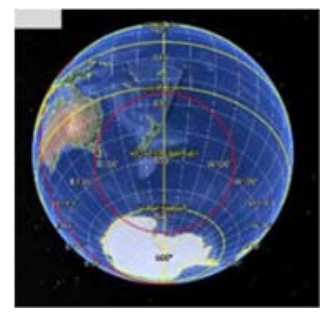

d- Circle of Greenwich city

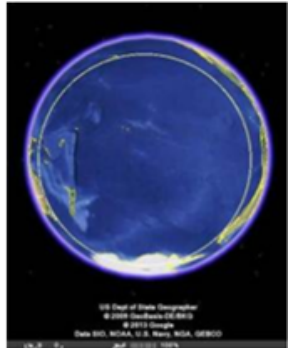

b Circle of Medina mosque.

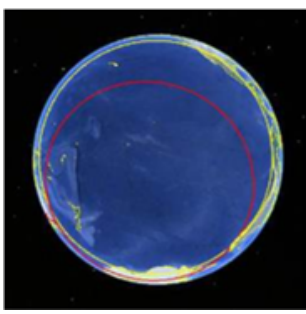

e- Circle of the Geographical center of the seven continents.
Figure 11: Four real satellite images. The circles do not pass through the outer edges of the new world continents as Mecca circle did (compare with figure 8) (the researcher).

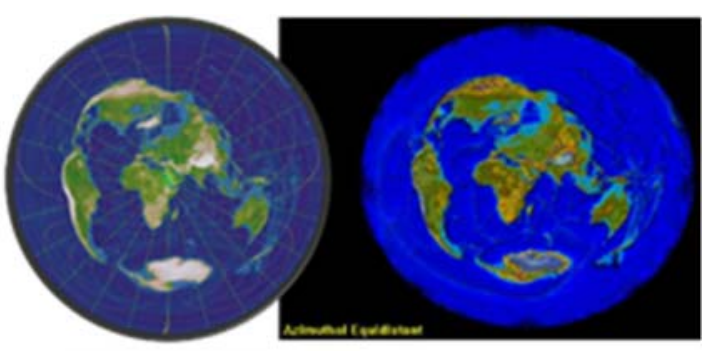

Figure 12: The equidistant azimuthal projection, centered on Mecca, and green lines showing the Qibla directions.

\section{CONCLUSION}

The accurate scientific measurements and the satellite images proved that the sacred mosque of Mecca (the Ka'ba) is the center of the dry land. It is found to be located in the center of four circles that pass through the edges of the dry land of the world's 
seven continents and the geographical centers of the new world continents.

Thus, the Ka'ba's global location is unique and incomparable. In accordance with the mentioned scientific evidences, it will be impossible to say that chance alone enabled the sacred mosque of Mecca, to play the role of being the Qibla for all Muslims.

It is Allah's choice and selection that includes great wisdom. When Muslims direct themselves toward Mecca (the qibla), they direct themselves to the center of the dry land. It should be also mentioned that the centrality of Mecca mosque on earth, facilitates the performance of pilgrimage for all Muslims from every corner of the world.

\section{REFRENCES}

[1] H. Gazi et al, "The position of Mosques in slamic cities and its location design in new cities", Damascus University Journal Vol. (28) - No. (1), 49-67, 2012

[2] A. Negotiate, "The city of Mansur the builder, Baghdad between the Caliph's will and Shari'ah norms". Pol. Sc. Int. Rel., VIII, 2, p. 111-126, Bucharest, 2011.

[3] Mahmūd Shukrī al-Alūsī, The Fulfillment of Desire on Knowledge of the Affairs of Pagan Arabs, ed. by Muhammad Bahgat al-Atharī, Vol. 1 (Beirut: Dār al-Kutub al-'Ilmīya, 1992), p.228.

[4] D.King, "The orientation of medieval Islamic religious architecture and cities, Science history publications, pp.254-274, 1995.

[5] David A. King, World-Maps for Finding the Direction and Distance to Mecca, Leiden, Brill, 1999.

[6] D. King, Too many cooks: A new account of the earliest Muslim geodetic measurements, Suhayl, 207-242, 2000 (available online at http:// usd.proves.ub.edu/suhayl/volums/volum1/ paper6.pdf)

[7] D. King, "Astronomy and Islamic society: Qibla, genomics and timekeeping", pp.128-184, (In: R. Roshdi (ed.): Encyclopedia of the History of Arabic Science, Vol.3, 2000).

[8] D. King, "Two Iranian World Maps for Finding the Direction and Distance to Mecca", Imago Mundi, 49: 62-82, 1997.

[9] M. Lottah, "Science and scripture: How did faith influence cartographic methods used to determine the qibla, the sacred direction of Islam?",

SPICA Postgraduate Journal for Cosmology in
Culture, Vol. IV No. 2, pp.12-31, Autumn 2016

[10] W.Tobler, "Qibla, and related, Map Projections", Cartography \& Geographical Information Science", $29(1): 17-23,2002$.

[11] H. Ahmed, "Mecca projection of the world". Journal of Islamic Research, General Secretariat of the Council of Senior Scholars, Saudi Arabia,; (6): 225- 244, 1971,(in Arabic).

[12] S. El- Marsefi, "The Kaaba is the center of the World", Dar Al- Manarah, El- Mansoura, Egypt, pp. 142-144, 2000.

[13] http://www.google earth.com (accessed on April 2016)

[14] http://www.al-habib.info/qibla-pointer (accessed on April 2016).

[15] http://www.movable-type.co.uk/scripts/latlong. html (accessed on April 2016).

[16] M. Saleh, "The two mosques: An introduction to their growth \& expansion \& their influence on their context through history",

Proceedings of symposium on mosque architecture, College of Architecture \& Planning, King Saud University, Saudi Arabia; vol.1B, 1-34, 1999 (in Arabic).

[17] http://www.enwikipedia.org/wiki/geographical_ center (accessed on April 2016).

[18] http://www.waymarking.com/waymarks/ WMY40_GEOGRAPHIC_CENTER_OF_AUSTRALIA (accessed on Mars 2016).

[19] Y. Wazeri, "Proving that Mecca is the center of dry land on earth", International Orgnization for Scientific Signs in Qur'an and Sunnah. Saudi Arabia, pp.34, 2015.

[20] F. Robert (ed), "The World almanac and book of facts", World Almanac Books, Mahwah, NJ, USA, 1998.

[21] http://www.cityofrugby.com/center.aspx (accessed on Mars 2016).

[22] https://en.wikipedia.org/wiki/Cuiab\%C3\%A1 (accessed on Mars 2016).

[23] Jerusalem city Coordinates are $31^{\circ} 47^{\prime} \mathrm{N}, 35^{\circ} 13^{\prime} \mathrm{E}$ (See https://en.wikipedia.org/wiki/Jerusalem (accessed on Mars 2016)).

[24] Medina city Coordinates are $24^{\circ} 28^{\prime}, 39^{\circ} 36^{\prime}$ (See http://www.latlong.net/place/medina-saudi- 
arabia-2246.html (accessed on Mars 2016)).

[25] Greenwich city Coordinates are $51^{\circ} 29^{\prime} \mathrm{N}, 0^{\circ} 00^{\prime} \mathrm{E}$ (See: http://en.wikipedia.org/wiki/Greenwich (accessed on April 2016)).

[26] The geographical center of Earth is the geometric centre of all land surfaces on Earth.

The geographical center of Earth Coordinates is $39^{\circ} 00^{\prime} \mathrm{N} 34^{\circ} 00^{\prime} \mathrm{E}$. (See: https://en.wikipedia.org/ wiki/
Geographical_centre_of_Earth (accessed on April 2016)).

[27] http://www.ncgia.ucsb.edu/projects/tobler/Qibla/ sdo01.htm (accessed on June 2016)).

[28] http://geographeratlarge.logspot.com.eg/2011/09 mapofweek9192011meccaatcenter. (accessed on June 2016). 